\title{
一般演 題
}

\section{看護・栄養（II）}

座長吉田公子

小児の転入における環境調整の 1 考察

透析者の環境についての考察（第 2 報）夫婦関係について…

善仁会高尾医院 矢沢 裕子, 林優子, 二木シヅエ

旭中央病院透析センター 菅本 英雄, 須合美津子, 伊藤 憲子 石毛 冷子, 栗林 春枝

長期女性透析者における生活状況の変化について

名鉄病院透析室今井和子, 多嶋多美子, 塚本 初恵 林子津枝, 板倉 和美, 佐藤 真理 伊藤 和子

増子病院 則 武

慢性透析患者の自宅での内服状況調査について… 本村 千鶴, 清水てる子, 小江美智子 高木佳代子, 小柳 幸栄, 相良千満子 原智子, 监島多美子, 安武 上口 福満 東馬

討論 


\section{小児の転入における環境調整の 1 考察}

矢沢 裕子 林 優子 二木シヅエ

善仁会高尾医院

〔はじめに〕成長期にある児が血液透析を受容し，日 常生活を円滑に軌道にのせていくには，児との関わりを 通して，多くの困難な問題が存在する。ここに性格上の 問題があると言われた児の受け入れに当たって，看護婦 側との詳細に渡る準備を, 行なう事で環境調整が出来, スムースに転入させるーが出来たので報告する。

〔症例〕 10 歳男児, 小学校 4 年在学中. 現病歴：小学 校入学時健康診断にて, 血尿, 蛋白尿を認め, ネフロー ゼと診断される。 その後, 高血圧, 検査值悪化の為, S 病院に入院透析開始となる.

〔研究方法〕1）S 病院透析室, 小览病棟の訪問と研 修。2）病院の主治医, 看護婦間のカンファランス. 3) 両 親との面接, 担任教師への働きかけ.4）看護基礎資料, 背景資料の作成.

[考察]初めての小児の受け入れにより，次の様な学 びを得た。1）研修，カンファランス，両親の面接を通し て，患児と両親を安定させ想定された問題を未然に防止 した。2）患児の復学への働きかけにより，通学を容易に した。

〔まとめ〕子供が病気の苦痛, 入院の様々な出来事を 克服し, 新しい環境に適応していく為には，子供をとり まく人間関係が最も大切な基本であり, 入院して医師, 看護婦と望ましい人間関係を構成する事が出来た子供 は, 自らの納得のもとに，治療と看護を受け入れ易いと 言われている。そして，病児は病気である前に子供であ る事をよく認識し，傷ついた子供には，出来るだけた たかいよい環境を提供する事が必要と考える。又，小児 と関わる者は，子供が正しく見られる様に，自分自身の 生き方をも問い続けていかなければならない.訪問研修 をさせて頂きました S 病院の皆々様に深く感謝致しま す.

\section{透析者の環境についての考察 (第 2 報)夫婦関係について}

菅本 英雄 須合美津子 伊藤 憲子 石毛 冷子

栗林 春枝

旭中央病院透析センター

透析患者と配偶者相互の愛情や愛着いかんで透析生活 のその後が左右されてくるといっても過言ではない.し かし, 透析を契機として家庭内の弱点や問題点が表面化 してくることがあることも指摘されている。また一般に 透析患者の性機能や性欲が低下していることも認められ ており，このことが夫婦の不和を生ずる原因となること も想像できる。
そこで, 今回われわれは既婚男性患者のうち 20〜40 歳 代で透析期間が 6 力月以上の 16 症例を対象に性生活と 夫婦関係また夫婦関係と透析成績について調べたので報 告する。

夫婦関係や透析成績は複雑かつ微妙なものと考えられ るのでスコア法を用い, 夫婦スコア・透析スコアとして 定量化することを試みた。

その結果円満な夫婦関係維持における性生活の必要性 を認める症例が多い（81\%）が，性欲や性交回数は健康 時と比較して明らかに減少していた。しかし，夫婦スコ アにおける性的満足度は大きな影響を占めてはいなく, 患者の経済力や妻に対する姿勢が関与していると考えら れた。

次に, 症例の年歯, 透析期間, 透析スコア及び夫婦ス コアの関係を検討すると，年歯及び透析期間と透析スコ アとには相関は認められず，また年歯と夫婦スコアにも 相関は認められなかった。しかし，夫婦スコアと透析ス コアには有意な相関が認められ，また夫婦スコアと透析 期間とに弱い逆相関を認めた。

以上より，円満な夫婦関係を支持する必要があり，そ の為就業への援助や妻に対するアプローチも必要である と考えられた。

\section{長期女性透析者における生活状況の変化について}

今井 和子 手島多美子 塚本 初恵 林子津枝 板倉 和美 佐藤 真理 伊藤 和子 則 武* 名鉄病院透析室 増子病院*

〔目的〕主婦である女性が長期透析を続けるにあたり どのような生活状況の変化が起きているのか調査し, 透 析者が自立していく上で，今後どのような働きかけが必 要か検討した。

〔対象・方法〕当院及び増子病院の透析歴 1 年以上の 36 歳〜 64 歳の主婦 26 名とその配偶者に無記名アンケー 卜調查を行った。

〔結果・考察〕1)長期透析治療を続けるうえで，透析 者の心の支えとなるものは家族の励まし，子供の成長を 糧とする者が $83 \%$ ある.2) 透析者の家族の透析治療への 関心は, 透析知識吸収方法が透析者から聞く程度であり, 正しい透析知識が家庭まで波及しておらず，予想以上に 低いと考えられる。3)透析者の自立には，透析者を取り 巻く家族の理解が必要であり，家族への教育は不可決で ある、4)透析者が家族へ依存することが，家族の日常生 活，ひいては社会生活に時間的制約をもたらしている. 女性の透析者の自立状態を考える時，透析者が病人意識 から脱脚しようとしても, 家族に病人意識からの脱脚が ない場合，結果的に透析者の自立意欲を妨げる事となる 
ので，透析者に最も影響を与える家族の意識変化が必要 と考えられる。

〔まとめ]主婦透析者が家庭内で透析治療以前と同様 の役割を果たすことを社会復㷌の第一歩と考え, 透析者 の家族には，透析知識の向上，コミュニケーションを深 める目的を，透析者には病人意識からの脱脚を図る目的 を今後の看護活動の計画とし, 主婦透析者が家庭という 社会で自立し，更に一般社会活動への参加を促す様努力 していきたい.

\section{慢性透析患者の自宅での内服状況調査について}

本村 千鶴 安武 ヒロ 清水てる子 小江美智子 高木佳代子 小柳 幸栄 相良千満子 原 智子 児島多美子 福満 東馬

福満クリニック

〔目的〕透析を行なう上で，薬物療法は重要な役割を 持つが，体重や検査結果に直ちに影響がでる食事療法と は違って, 自宅での服薬状況は把握しにくいのが現状で ある。そこで当院で毎週処方されるアルミゲルを中心と した定期薬について，家庭での服薬状況や薬に対する認 識度について，調息を行なった。

〔対象・方法〕当院の透析患者 23 名を対象に質問紙法

\section{討 論}

渡辺(嬉楽堂病院) 矢沢さんの演題に対してですが受 け持ちナースでやったら，患者さんがうまくいったと あったのですが，どのくらい受け持ちナースの期間とし て受け持たれたのかという質問と，反抗的な態度が受容 的に変わつたという変わり方, 反抗的な患者さんという のは,なかなかうまく変われないと思うのですけれども, その辺がどういうふうに変わって，看護していく上でや りやすくなったかということを知りたいのですけれど も.

矢沢 最初のご質問ですが，受け持ちナースは，訪問 と研修を行った際に，まず行った人が受け持って，うち の病院での受け持ちもやはり同じ人が当たって，空口を 作るのです。必ずこの子供の問題はこのナースにという ことで，必ずその受け持ちのナースを通して，患者の家 族または子供へという具合に行いましたけれども。

二つ目は，この研究の一番のポイントだと思うのです が，問題のある子供に対して，どうしたら私たちはその 子供をうまく転入させることができるかという問題だと 思うのです。そういう子供であったから，私たちはその 病院を訪問して，その子供に本当に歓迎しているんだ，
による無記名アンケート調査を行なった。

〔結果〕1) 薬を必ず飲んでいる人は 23 名中 13 名 (57\%) で，高年齢層に多かった。2) 薬をたまに，また は時々飲み忘れる人は 23 名中 10 名 $(43 \%)$ で，まった く飲まない人はいなかった。3）確実な服薬ができていな い理由で最も多いのは「外出の時，持っていかないから」 であった４）薬を確実に飲んでいない人は，透析歴 1 年 〜 5 年末満, 年齢で 30〜 40 代に多かった. 5) 薬を飲さか 否かは，薬に対する知識の深さに相関しなかった。6)長 期服薬に対する不安は，透析初期の人に多かった。

〔考案・結語〕透析の導入期から透析療法, 食事療法 の指導と同様に，薬についても個人の理解度に合わせた 具体的な指導により，不安の除去に努める必要がある。 また働き盛りで活動的な 30〜 40 代, 透析 1 年〜 5 年の中 だるみの時期の人にも服薬の習慣づけ，薬についての知 識の再教育が必要である。慢性腎不全の治療は，飛躍的 な発展を遂げ，今後も益々，向上し患者の治療期間も長 期にわたると考えられる。それに伴い，骨代識，神経障 害，その他長期透析にまつわる種々の合併症が起ってく る事が予想される，従って，食事療法と同時に，薬物療 法の重要性を患者に充分理解させ，薬を正しく飲んでも らう事が必要だと思われる。

私たちは，こちらの病院であなたのことを待っているん ですよという思いをその子供に伝えることが，まず第 1 の看護の方法でしたね.

小川(国分寺南ロクリニック) 本村さんの演題につい て質問ではないかもしれませんけれども，以前ちょっと 疑問に思ったことがあるのです。透析患者に対する内服 薬というのが，大変な量で，それが最近ものすごくカラ フルになりまして称，扮小水が出ない人に，ああいうの の，人体に対する影響というのはちょうど内服薬とい うことが出ておりましたので，そういうことは扔考えに ならなかったのか，患者さんのそういうものに対する恐 れというふうなもので飲まなかったとか，そういうこと は全然考慮になかったんでしょうか.

本村 副作用についての心配は，今度のアンケート内 容でも幾つかありました。薬物療法というのは，医師の 分野にもなるのですけれども，極力必要最小限にとどめ てはいます。特に，薬について誤った考え方を持ってい らして，飲まない理由で，例えばワンアルファーを飲ま ない理由で聞いていると，全然違ったふうな考え方を 持っていらうしゃる方がいらして，飲まないということ 
を聞いたりしましたので，その場合は個別にそれぞれ必 要最小限の薬についての必要性を分かりやすく説明をし

ています。

\section{初心者のための 血液透析の手技と和護}

目黑駅前クリニック院長 河 野 南 雄
東京慈恵会医科大学講師

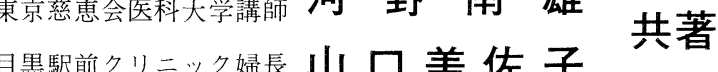
A /5判 106頁図表73 定価 2,500. (送料250.)

これから，あるいは現在，透析室に勤務するナース，テクニシャンの方のためにを 目標に手技と看護の実際を，写真および眓解でわかりやすくまとめた。

\section{【主要目次】}

人工腎臓とはノショックの予防と対策／人工腎臓装置一式のしくみ／透析液供給装置の準 備／穿刺の準備ならびに注意事項／穿刺手順／透析条件の設定／透析終了時の操作手順／ ECUM (イーカム)/透析看護に必要な基礎的理解／偶発症もしくは事故対策／日常生活 の指導のあらまし／著者らが経験した事故の反省／自己管理のあらまし一とくに水分はと りすぎないように一 